\title{
Recruitment System Of Candidate Civil Servants In The Regional Autonomy Era (Study on Regional Employment Agency Government Malang Indonesia)
}

\author{
Sutrisno, Agus Suryono, M. Saleh Soeaidy,Mardiyono
}

\begin{abstract}
Proceduresandimplementation ofthe system of recruitmentcandidates for Civil Servantsare veryvulnerableandthe potentialtospoilthe practice ofsystemandNepotism. One effortshould be made tominimize therecruitmentviolationsareapplyingmerit system. Byprovidingjoborientationis notbased on race, ethnicity, religion, politicalaward, genderdiscriminationandpersonalfavoritism. This study used a qualitative approach, with a focus on Recruitment Process System Candidates for Civil Servants at the Regional Employment Agency Government of Malang Indonesia. The results showed the recruitment process requires harmonization of policies, especially the problem of proposing and charging formations, where the determination of the formation still is top down and discriminatory conducted by officials of the central and regional staff development, while the job analysis and workload also needs to be studied further in order to create an effective bureaucracy. The study also recommends that the merit system is very fitting applied to recruit employees in Indonesia. Merit system is expected to minimize collusion and nepotism in the recruitment process.
\end{abstract}

Keywords:system recruitment, civil servants, local government, merit system.

\section{Introduction}

Employeesareorganizational resourcesthat are usedtomoveormanageother resourceseffectively andefficiently according tothe needs ofthe organization. Therefore,recruitmentplanningmust bedone preciselyaccordingworkloadandneeds of the organization. Mondyet al(1996) mentioned thathumanresource planning(HRP) istheprocess resourcerequirementssystematicallytoensurethattherequirednumbersofemployees, therequiredskillsareavailablewhentheyareneeded.Human resourcesis a critical factorinan organizationorgovernmentin providing servicesto the public(Baedhowi, 2007). Meritsystem isactually intendedtoobtainqualified personnel.Bureaucratic reformsbeingcarried outinIndonesiarequires the supportof humanresourcecompetenciesin thefield of work. Changes inthe strategicenvironmentof the 21 st centuryresulted inmajor changesin theimplementation of thenational developmentof Indonesiain particularthe availabilityof resourcesfor Civil Servants. Contribution ofcivil servantsis verydominantandstrategicin theprocess of achievingnationalgoals. Therefore, effortstokeepthe availabilityandimprove the quality ofcivil servantsneededtobe able toguarantee thequality ofthe Civil Service(Haksoo.2008).

Recruitmentis to obtainqualified staff, theemployeeswhoare smart,skilledandcompetent, able toworkhard, creative, andhighmorality. However,the implementation is stillnotas neededwhich cansupport the success ofthe performanceandprofessionalismof employees. This conditionis causedby astaffingplanthatis notbasedon the real needsarematchedwiththe needs ofthe organizationandstaffingthat are notbased on theprinciple ofthe right manon the rightplace. Research conducted by Madelin (2008) about the study of recruitment and selection policy analysis of civil servants in Indonesia found that the recruitment process in Indonesia has found the practice of bribery and nepotism, which could potentially lead to corruption in the future. Recruitment and selection of employees with nepotism through political relations, family and kinship adversely affects the quality of civil servants. Root causes ofcivilserviceinIndonesiainprincipleconsistsoftwoimportantthings: (1) the internal problemsof the staffing system(2) externalissuesthat affect thefunctionalityandprofessionalismof personnel.

Internal problemsstaffing systemcan be analyzedby observingsubsystemsthat make up thepersonnel. Civil servicesubsystemconsistsof: (1) recruitment, (2) payrollandrewards, (3) performance measurement, (4) promotion, (5) monitoring. The government's failureto reformassociated withthesubsystemcangive birthbureaucratscharacterizedbymoral corruption(moral hazard) and also thelack ofcompetencies(Prasojo.2006). The recruitment process is still not done professionally and is still associated with the relationship of collusion, corruption and nepotism. Recruitment is still viewed as if becoming an annual project needs and not as a need for improving the quality of public services and governance. The very real indication that when seen as a job analysis to determine job requirements equipment still owned by the government. The absence of work requirements have led to the recruitment done recklessly and not paying 
attention to the qualifications required. That is why, despite the perceived civil servants in Indonesia do not know what they are doing, but the recruitment of candidates for Civil Servants still continues. To be able to do with either the recruitment process, the specification of tasks and positions should be well known. (Prasojo. 2006)

Research conductedbyGossett(2002) about the reform ofthe stateapparatusinGeorgiafoundthat themerit systemhas broughtchanges rangingfromrecruitmenttotheplacement, decentralizationoremployeemoral responsibility.Withameritsystemthat is detached frompoliticalintervention, theprocess ofrecruitmentis donethroughthe process of election, selection andplacementonlyto thosewhoareobjectivelysuperior becauseall theprocessesare carried outin an open andknown by the public. In addition,this policyis able tochange thecharacter ofemployeesandfreeingthemfromvariousforms of racial discrimination, skin, national origin, sex, age, disabilityandreligion.

Conditionsareillustratedin a study conductedbyMadelin(2008) andGoseett(2002) is interesting to further research in therecruitmentprocessinIndonesia, which isallegedlystilldopracticenepotism. Problemrecruitment of civil servantsinIndonesiaisthe emergence ofpracticecronyismandbrokering. The practicehas been going onsolong, becausegovernanceisnotgoodrecruitment. Thereare twodespicablepracticethat oftenoccurin therecruitment of civil servants, thecollusionandcorruption.

Collusionandcorruptioncanbedone simultaneouslybecause thetwo concepts areverythindifference, synonymouswiththe practice ofspoilsystem thathas been entrenchedin the midst ofsociety. These conditionscan beavoidedif the governmentis able tomakethe planningneeds of employeeswhoadopt amerit system. The studyis expectedto contribute totheacademicdevelopment ofpublic sectorpersonnel administrationrelated to planning, filingformation, recruitment, selection,andstaffing. The resultsof this studyare alsoexpected tocomplete thestudyof personnel administrationin the context ofregional autonomyinIndonesia. Practically, the results ofthe studyare expected toprovideimprovements to thesystemof personnel administration.

\section{ApparatusResource Management inPublicAdministration}

\section{Theoritical Framework}

Study of public administration evolve with the changes that occur in a country and the complexity of the problems faced by public administrators. Denhard and Denhard (2003) states the main perspectives that occur in public administration, namely the Old Public Administration (OPA), (2) New Public Administration (NPM), and (3) New Public Service (NPS). While strategies need to be developed and pursued by administrative agencies in the era of globalization is increasing the quality of human resources, improvement of the quality of public services and increased sensitivity to the environment. Thirdly it is strongly associated with more specialized apparatus to recruitment problems as a sub-system of human resource management.

Providingemployeesrelated torecruitment and selection. Mondyetal(1996) definesrecruitmentastheprocessofattractingsuchindividualsinsufficientnumbersand encouragingthemtoapplyforjobswith theorganization. ThenMonappaandSaiyadainas quotedbyMangkunagara(2003), arguesthatrecruitmentisthegeneratingofapplicationsorapplicantsfor specificpositions. Whilethe selectionis definedbyMondyetal(1996)astheprocess ofchoosingfroma group ofapplicantstheindividualbestsuitedfor aparticularposition.

In theprocess of fulfillingthe needs ofthe organizationapparatusof publicresourcesmustimplementthe planningprocessneedsof employees. The process iscarried outtopredictthe resourcesrequiredby theorganization'spersonnel. Ivanevich(1995) suggest that with theplanning of theemployeeneedsto know the amountandtype ofwork to bedonein an organization. Planningis an activitytoobtaininformationaboutthe needs of employeesin thefuture. In additiontohis plannedtypesas well asthe expertiseandcapabilities of theemployees, then theorganizationwillgetthe appropriateandqualifiedemployees. In addition to gettingthe right peopleandthequalityof personnelplanningis necessarytoanticipatethe problemsthatariseabout theadvantages and disadvantagesof employees(Amstrong.1990)

\section{Merit System in Indonesia}

Personnel resourcesisa veryimportantresourcein the context ofgoalachievement. It is recognizedbyMcLeod(1999), whosaidthat thepersonnel resourcesas avaluable resource. Becauseemployeesarea valuable assetin an organization, theprocurementplanninganddevelopment needs to bepreparedas well as possible.TogainvaluableHuman Resources, recruitmentshould bebasedskillssystem(merit system) which is oneof the important characteristicsof rationalbureaucracyaccording to Weber,theemployeereceivedon the basis ofabilitynotkinship ties(Henry.1988).

Recruitmentbased on meritas evidencedcompetitivelyasHenrysaid, according to Riggs(1984)is usedasthe initial model(prototype) byadvancedandmoderngovernmentlikethe UK, USA, AustraliaandNewZealand.Systemskills(merit system)adoptedbycountrieswithwesternpoliticaltraditionasthese countries, generatingqualified staff, experts, andprofessionals.TannerandFeder(1993) revealedthat 
therecruitmentprobleminmost developing countriesisnepotismandspoilthe systemasthe consequenceofpolitical developmentsunanticipated.Toobtainqualified staffand competitivecan be donethroughvariousstrategiesincludingsetprincipleof centralizationanddecentralizationin policy formulationin theexecutiveness (Kristiadi. 1996).

In addition, efforts toincreasethe effectiveness of variousstrategiesforthe qualityof personnel resourcesrecruitment and selectionbegan. Mondy et al(1996) definesrecruitmentasthe process of attractingapplicantsin thejobopeningin an organization. Candidatestofillvacanciesorganization, cancome fromwithinthe organization(internal source) or from outside theorganization(external source).To get quality human resource planning needs to be done right and measurable recruitment system. Simamora (1999) stated that recruitment is a series of activities to locate and lure job applicants with motivation, abilities, skills and knowledge required to cover deficiencies identified in the staffing plan. Furthermore, Downs (1967) said recruitment is very important for the organization, therefore it is rational for each organization to recruit the right. Meanwhile, Kenna (1995) said recruitment is a process of retrieving a group of candidates to fill vacant positions.

The selection processimplementedtoensurethatrecruitmentis donebyusing themeritsystem. As confirmedbyCole(1937) that theappointment ofpublic servantsshoulduse amerit system. Therefore, the selection processbeginsfrom thereceipt ofthe applicationandendswith adecisionontheapplication. As statedMondy et al(1996), employeescan berecruitedfromqualifiedemployeesfromwithinthe organization, or from outsidethe organization(external source). Selectionof prospectiveemployeesis doneto geta high qualityemployee. The quality oftheprospectiveemployeecan befulfilled if themerit systemcan beimplemented. Islamy(2001)saidthat themerit systemshouldensure that allpeoplecanapply for jobs, butin the end theyarethe most qualified(the mostqualified) to choose andget a job. Recruitmentand selectionrecruitmentis animportant activityin the field ofresourcemanagementpersonnel.

The application of the merit system compatibility between the skills possessed by an employee of the office entrusted to him, including the level of formal education, non-formal education, technical education and training, work experience level, and the level of mastery of tasks and jobs. While the factors that affect the application of the merit system of promotion policy includes regulatory, external control and the commitment.

Recruitment model is based on merit, competence, expertise and experience of the candidate and thereby spoil the type of recruitment system can be eliminated. By applying the type of merit system, employees who pass the selection guaranteed to have a good quality that can support more optimal performance for the bureaucracy in the future. Furthermore, to achieve this goal, there are also some things that need to be considered in order to reform the bureaucracy, among others: First, Transparency. In the middle of the swift currents of public demand for the establishment of good governance, the principles of openness should also adds a mechanism of recruitment candidates for Civil Servants. This was done in an effort to create a bureaucratic performance that is open and transparent in conveying accurate information to the public about the selection mechanism. Second, public accountability. Selection of Candidates for Civil Servants acceptance is closely related to the public interest, so the entire action, behavior and activity as well as any policy in the bureaucracy should also be accountable to the public. Instead, people should be more proactive to perform the control functions of the bureaucracy so that all duties and responsibilities are carried out by bureaucrats both administratively and functionally oriented commitments and alignments for the public interest. Third, professional service. Quality services to the public bureaucracy very influenced by various factors such as: quality of leadership within the bureaucracy, its service procedures must be efficient, simple, easy to reach at all levels of society, precise, clear and safe.

In addition, to further optimize its services to the public, particularly in relation to the recruitment of candidates for Civil Servants, the position should be neutral as a bureaucratic government machinery that perform administrative tasks and operations proportional, rational, objective. This is important as part of efforts to prevent various forms of intervention and conflict of interest between individuals or groups that could lead to bureaucracy cannot work effectively, professional and independent.

Nowadays the concept of "merit system" being implemented in the hope of bureaucracy will be more professional and more neutral because it is supported by appropriate personnel with expertise and have high competence. By invoking the merit of this system will bring the development of national and state towards the better.

\section{Research approach}

\section{Methodology}

This study uses qualitative research is a research that seeks to observe a particular phenomenon or problem in depth in the context of a particular environment. The phenomenon in question is candidate recruitment system for civil servants in Local Government Personnel Board Malang Indonesia". 
Based ontheresearch problemhas beenformulated, themainfocus ofthe studyincludetherecruitmentsystem, the implementation of recruitmentsystemandidentify the factorsthat influence.In accordance with the research objectives, the type of data associated with the recruitment system of civil service candidates include (1). data from informants such as; Head and secretary of the local civil service agencies that deal with procurement officials and interviews with other relevant informants. Secondary data such as the Law, Government Regulation, Presidential Decree, the Minister and the publication in the mass media.

In analyzing the data of this study refers to the theory of Interactive Milles and Huberman (1992). Qualitative data analysis is done interactively and lasted continuously until completion. Interactive data analysis includes the following steps (1) Data reduction is the process of simplification of the data in a way sort through, categorize, directing choose the data corresponding principal focus of research. (2) Presentation of data is an important second groove of the data analysis activities. Presentation of data is a set of data / information that has been arranged which gives the possibility of drawing conclusions and taking action. Lam presentation of research data in the form of frequency tables, diagrams and charts as well as narrative. (3) a conclusion or verification is based on the results of data reduction and presentation of the data obtained at each stage.

\section{Validity of Data}

There are four criteria used for to check the validity of the data. (1) the degree of confidence in the observational studies were conducted through continuous, sustainable and continuous so that researchers can see the phenomenon more closely, and more in-depth detail about the prospective employee recruitment system. (2) transferability is used to see to what extent the results of this study can be used in certain contexts and situations. (3) dependability is the criteria for judging whether or not the quality of research. The way to establish that the research process can be maintained by performing internal and external audits. (4) Confirm ability is the criteria for assessing the quality of research results.

\section{Results}

Problematic recruitment of candidates for Civil Servants in Indonesia is an external force that drives the political interference in the recruitment process. This is due to the bureaucracy in Indonesia is still not completely separated by politics. The desire of certain parties (e.g. political parties) to make the bureaucracy as a political machine influence reform efforts in recruiting candidates for Civil Servants (Prasojo.2006). Associated with the reform of the bureaucracy, political party commitment to promote a change in the recruitment process will result in improved recruitment process candidates for Civil Servants in Indonesia. Implementation merit system in the civil service recruitment is very suitable candidate. Merit system is intended to reduce collusion that often occur in any recruitment event.

Merit systemin the process ofrecruitmentandimplementationof civil service candidatescan be held properlyifthere ispolitical will from thegovernmentas theorganizer ofrecruitment. Politicalinterestthat allows thecorrupt practicesshouldbe avoidedin order toproducecivil servantswhohaveintegrity, credibilityandcompetency.

The economic aspectis veryimportantin encourage the process ofrecruitmentandimplementation ofsystem changes. It isrelated to thefinancingneeds oftherecruitmentprocess. Public expectationthat government can makethe processin a professionalandresponsibleneed supportinfrastructureincludingsystemsandproceduresbetter.

Discourserecruitmentprocessbyusinginformationtechnologyrequires alarge investmentandhumanresourcereadiness.

Research findings for factors in habiting recruitmentprocessandimplementationispoliticalintervention. Thispoliticalinterventionoccursin a "hidden mechanism"performedbyactors whoare involvedin therecruitmentprocess.Pragasam (2004)saying that in principle recruitment is fundamental to creating a relationship between the applicant with an opportunity. This is in accordance with the recruitment function is to get as many applicants that the organization has wide opportunity to determine the choice of candidates for employment are considered to meet the qualification standards organization. Meanwhile, by Gatewood and Feild(2001) suggested that the purpose of recruitment, among others, are as follows. Firstly, increasing the number of applicants at a realistic cost. Secondly, social and legal obligations associated with the organization of the demographic composition of the labor force. Thirdly, to help increase the level of the success of the selection process by reducing the percentage of applicants who are not qualified.

In the recruitment process, the quality of the participants, the media used, and the weight of the loaded information into a very important factor and determines the success of the recruitment process. Adler (2004) suggested that the implementation of good recruitment would at least reduce the level of turnover and encourage organizational effectiveness and job satisfaction. 
Merit systemthatemphasizes thecompetencytoworkandrefusepatronageassociatedwithpolitical connectionsandloyalty. Merit systemofferscontinuityandstabilityinstaffingwhileallowingthe executivepatronagechoosea loyalsubordinate(Gordon.1982, Kamoche.1994).Further bylto(2002) explainedthat themeritsystemis theunderlyingprinciplesof universalreform model, which is basedonequalityandquality. Means,opportunitiestoapply for jobsopen aspossibleso as to enableallpeople canapply, butonly the bestareselected.

\section{Summary}

Recruitmentis based onmeritis defined asneutrality, equality, fairness, andcompetence. In theinternational contextof justiceandequalityare seen asthe mainlegalbasisof recruitment. Selectionof employeesin countriesthathavedevelopedinapplying thegeneralmerit systemand avoidunnecessary politicalinfluence.Improving the quality ofemployees based onmeritincludemanyaspectswhichthe selectionis competitive, unilateraldismissalprotection, the protection ofpoliticalneutrality, as well asthe establishment ofan independentemploymentagency(Shepperd. 2003). Thus, the mainmeasure ofrecruitmentand selectionisbased onmeritsystemof appointmentof candidateswhomeet the criteria ofeffectivenessandefficiencyin providing servicesto the community, withoutignoring theemployeeethics.

In order to fulfill the basic principle of the merit system, the requirements set forth in the recruitment and selection is usually quite tight which includes general requirements, skills, talents, temperament, character, motivation and morale. In addition, employees also formulated standards of competence, conduct, and moral responsibility with regard to the authority of, as well as its position as the employees who serve the public. However, implementing merit-based recruitment is not easy difficulty is faced by both developed and developing countries.

The tendency ofthe implementation ofrecruitmentand selectionthat occursisonlydirectedattentiontothe selectionin order toobtain thebestcandidateamong theapplicants, notgeared toattract thebestin the labor marketto participate asapplicants. Therefore, it needsa strategyto attracthigh caliberapplicantsby offeringcompetitiveremunerationwhich includessalary, benefits andcareer paths.

The issue ofrecruitmentand selectionactually coverstwomajorissuesarehow toattract peoplewhowant tohave the abilityto applyandthenmaketheappropriateselection, open, andfairso thatonly qualified applicantsthatcanbe acceptedas an employee. Toensure the implementation ofthe merit system, the governmentshould includerecruitmentand selectioncriteriaarefirmlyandthenput itin thelegislationin thefield of personnel.

\section{Reference}

[1]. Adler, G, 2004, The neglected role of labor relations in the South African public service. In G. Adler (ed) 2000, Public Service Labor Relations in a Democratic South Africa a Compilation of Papers.

[2]. Armstrong M (1996) A Handbook of Personnel Management Practice, 6th ed, Kogan Page, London.

[3]. Baedhowi.2007.RevitalizationApparatus Resourcesinthe Context oflmproving the Qualityof PublicServices. Journal ofAdministrationandOrganization, BusinessandBureaucracy, Vol.15, No.2 (May).

[4]. Denhardt, J.V. \& Denhardt, R.B. 2004. The New Public Service: Serving, Not Steering. New York: M.E. Sharpe.

[5]. Downs, Anthony. 1967. Inside Bureaucracy. Boston: Little, Brown.

[6]. Gatewood, R.D., \& Field, H.S. 2001. Human resource selection (5th ed.). Mason, OH: South-Western.

[7]. Gordon W. 1982. Merit Systems Protection Board, Respondent United States Court of Appeals, District of Columbia Circuit. - 802 F.2d 537 Argued Dec.

[8]. Gossett, Charles W. 2002. Civil Service Reform: The Case of Georgia. Review of Public Personnel Administration, 22(2), 94-113.

[9]. HakSoo, Lee, 2008. Changing Federal Government Employee Attitudes Since the Civil Service Reform Act: Review of Public Personnel Administration.

[10]. 2008. Dissertation Abstracts International, Volume: 52-08, Section: B, page: 4346

[11]. Henry, Nicolas.1988. Public Administration\& Public Affairs, Pearson Prentice Hall-USA.

[12]. Islamy, Irfan 2001.The State Administration Reform Policy Agenda. Journal State Administration: Good Governance, Vol. II No 1, September 2001. FIA Unibraw Malang.

[13]. Ivancevich, John M. 2001. Human Resource Management, New York: Mc. Grow Hill Companies.

[14]. Kamoche, K. (1996) Strategic human resource management within a resource-capability view of the firm. Journal of Management Studies, 33(2), 213-233.

[15]. Kenna, Quinet, 1995. "The Indianapolis Police Department Police District Community Policing Baseline Reports (North, East and West)." Center for Urban Policy and the Environment, Indianapolis, IN July, September and October.

[16]. Kristiadi, J.B., 1996. "Administrative Reform in Indonesia: Streamlining and Professionalizing the Bureaucracy," in Charles Heckscher and Anne Donnellon, Op.Cit., p. 97-109.

[17]. Madelin, Kusharwati. 2008.RecruitmentandSelectionPolicy AnalysisPNS. DissertationGraduate Program, University of Indonesia, Jakarta.

[18]. Mangkunagara AP., 2003.Planning and Human Resources Development. Bandung: PT RefikaAditama.

[19]. McLeod, Ross H., 1999. "Reformacy in South Korea", in Ross Mc. Leod and Ross Garnaut (ed.), East Asia In Crisis: From BeingA Miracle to Needing One?, London and New York : Roudlegde.

[20]. Miles andHuberman, 1992.Qualitative Data Analysis, translation TjetjepRohandiRohidi, University of Indonesia Press. Jakarta

[21]. Mondy, Wayne \& Robert M. Noe., 1996. Human Resource Management, New Jersey: Prentice Hall Inc.

[22]. Prahalad, C. K. 1990. The Core Competency of the Corporation. Harvard Business Review, Mei - Juni. 
[23]. Pragasam Raj Gnana, 2004. "Management Recruitmen: Current and Future Models For The Service Industry" New Jersey, page 273.

[24]. Prasojo, Eko. 2007.Reformof Civil Service(Civil Service Reforms) inIndonesia: Civil ServiceReform, Journalof Public AdministrationVolVIINo.1FIAUBMalang.

[25]. Riggs, F.W. 1984 "The Ecology and Context of Public Administration: A Comparative Perspective" in Public Administrative Review, Volume 40 No.2, pp.107-115 http://www.jstor.org/stable/975620.

[26]. Shepherd Geoffrey, 2003. Civil Service Reform in Developing Countries: Why Is It Going Badly? 11th International AntiCorruption Conference, 25-28 May 2003 Seoul, Republic of Korea. Panel: Depoliticizing the Civil Service, Tuesday 27 May, 2003.

[27]. Simamora, H. (1999), Human Resource Management, Publishing Section of Economics YKPN, Yogyakarta.

[28]. Tanner and Feder, 1993.Overview: A Brief History of Federal Welfare Reform. Breaking up Families Disincentives to Work Relationship to Crime Levels Replacing Welfare with Private Charity. 